\title{
PENGARUH INSENTIF PAJAK, FINANCIAL DISTRESS, EARNING PRESSURE TERHADAP KONSERVATISME AKUNTANSI
}

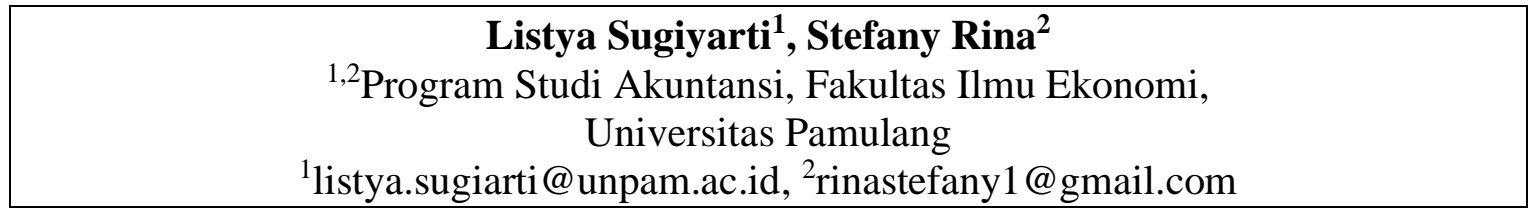

Diterima: Februari 2020; Disetujui: Agustus 2020

\begin{abstract}
This study aims to obtain empirical evidence of tax incentives, financial distress, earnings pressure and accounting conservatism. The influence of the independent variable on the dependent variable in the study uses secondary data in the form of financial statement data in the manufacturing companies of the consumer goods industry sub sector listed on the Indonesia Stock Exchange in 2013-2017. This research used quantitative methods. The sample used in this study amounted to 19 manufacture companies of consumption goods industry sub-sector with a research observation period of 5 years and obtained a total final sample that can be processed as many as 95 financial statement data. Data analysis techniques used multiple linear regression with statistical tests and the operation of SPSS software version 24. The results of the study showed that tax incentives affect accounting conservatism, financial distress influences accounting conservatism, while earning pressure does not affect accounting conservatism.
\end{abstract}

Keyword: accounting conservatism, earning pressure, financial distress, tax incentive

\begin{abstract}
Abstraksi. Penelitian ini bertujuan untuk memperoleh bukti empiris insentif pajak, financial distress, earning pressure dan konservatisme akuntansi. Pengaruh dari variabel independen terhadap variabel dependen dalam penelitian tersebut menggunakan data sekunder berupa data laporan keuangan pada perusahaan manufaktur sub sektor industri barang konsumsi yang terdaftar di Bursa Efek Indonesia pada tahun 2013-2017. Penelitian ini menggunakan metode kuantitatif. Sampel yang digunakan pada penelitian ini berjumlah 19 perusahaan manufaktur sub sektor industri barang konsumsi dengan periode pengamatan penelitian selama 5 tahun dan diperoleh total sampel akhir yang dapat diolah sebanyak 95 data laporan keuangan. Tehnik analisa data menggunakan regresi linier berganda dengan uji statistik dan pengoperasian software SPSS versi 24. Hasil penelitian yang dilakukan menunjukkan bahwa insentif pajak berpengaruh terhadap konservatisme akuntansi, financial distress berpengaruh terhadap konservatisme akuntansi, sedangkan earning pressure tidak berpengaruh terhadap konservatisme akuntansi.
\end{abstract}

Kata kunci: konservatisme akuntansi, earning pressure, financial distress, insentif pajak

\section{PENDAHULUAN}

Proses manajemen perusahaan harus dilakukan dengan kehati-hatian dan dapat mempertanggungjawabkan segala bentuk kegiatannya. Laporan keuangan merupakan salah satu bentuk pertanggungjawaban manajemen perusahaan. Pertanggungjawaban atas laporan keuangan dalam menjalankan pengelolaan sumber daya perusahaan yang telah dipercayakan oleh manajemen berisi informasi relevan dan handal bagi berbagai pihak.

Sesuai Pernyataan Standar Akuntansi Keuangan No. 1 tentang Penyajian Laporan keuangan, pada paragraf ke-7 menyebutkan bahwa tujuan dari laporan keuangan untuk 
memberikan informasi posisi dan keadaan keuangan, kinerja keuangan dan arus kas entitas yang bermanfaat untuk sebagian besar pengguna laporan keuangan dalam pembuatan keputusan ekonomi. Standar Akuntansi Keuangan (SAK) memberikan fleksibilitas bagi manajer yaitu memilih metode akuntansi yang akan digunakan dalam menyusun laporan keuangan. Metode akuntansi yang dipilih oleh manajer perusahaan ini didasarkan kepada kondisi perusahaan yang ada. Guna mengantisipasi kondisi perekonomian yang tidak stabil, manajer diharapkan dapat berhati - hati dalam penyajian laporan keuangan, khususnya pada pengakuan ataupun pengukuran angka - angka pada laporan keuangan tersebut. Bentuk kehati-hatian yang dilakukan oleh manajer perusahaan adalah mengakui bentuk biaya atau kerugian yang kemungkinan akan terjadi, akan tetapi tidak langsung mengakui pendapatan atau keuntungan yang akan datang meskipun kemungkinan besar terjadi (Handayani, 2015). Prinsip dasar yang digunakan dalam penyusunan laporan keuangan perusahaan salah satunya yaitu penerapan prinsip konservatisme. Arti dari konservatisme akuntansi adalah prinsip kehati-hatian dalam pelaporan keuangan dimana perusahaan tidak langsung terburuburu dalam mengakui dan mengukur aktiva, laba/keuntungan dan segera mengakui kerugian juga hutang yang memiliki kemungkinan yang terjadi (Savitri, 2016:22). Menurut Glosarium Pernyataan Konsep No.2 dalam FASB (Financial Accounting Statement Board) konservatisme didefinisikan sebagai reaksi kehati-hatian (prudent reaction) untuk menghadapi ketidakpastian pada perusahaan, untuk mencoba memastikan bahwa ketidakpastian dan risiko pada lingkungan bisnis yang sudah dipertimbangkan. Penerapan konservatisme Akuntansi pada perusahaan dapat dipengaruhi oleh beberapa faktor, yaitu insentif pajak. Insentif pajak ialah suatu pemberian fasilitas perpajakan yang diberikan kepada investor dalam ataupun luar negeri, untuk aktivitas tertentu atau suatu wilayah tertentu yang dapat mempengaruhi kegiatan ekonomi (Sumantri, 2018). Pada kawasan Asia terdapat beberapa negara yang saling bersaing untuk memainkan insentif pajak dengan tujuan dapat menarik investasi asing yang diyakini oleh perusahaan mampu memulihkan keterpurukan ekonomi pasca krisis ekonomi tahun 1997-1998 (Rahayu, 2018). Wicaksono dan Laksito (2012) menyebutkan bahwa perubahan tarif pajak dari tarif progresif menjadi tarif tunggal memberikan pengaruh tersendiri untuk perusahaan. Apabila manajer berusaha dalam memaksimalkan nilai perusahaan dan meminimalkan beban pajak, maka dengan demikian perubahan tarif tersebut akan memberikan insentif bagi manajer dalam melakukan konservatisemi akuntansi. Perusahaan biasanya akan menerapkan strategi meminimalkan pajak (taxminimizing) dengan cara melaporkan laba/keuntungan lebih rendah. Selain insentif pajak, financial distress juga dapat berhubungan dengan konservatisme akuntansi. Konsep teori akuntansi positif mengatakan bahwa manajer peruahaan akan cenderung mengurangi tingkat konservatisme akuntansi apabila perusahaan mengalami tingkat financial distress yang tinggi. Faktor financial distress dimulai pada saat perusahaan tidak dapat memenuhi kontrak hutang kepada kreditur atau mengalami kesulitan dalam pembayaran hutang kepada kreditur. Pada kondisi tersebut, pemegang saham dapat melakukan penggantian manajer perusahaan pada saat perusahaan memiliki masalah kondisi keuangan, atau dapat juga menurunkan nilai pasar manajer yang bersangkutan di pasar kerja. Tindakan tersebut dapat mendorong manajer dalam mengatur pola laba akuntasi yang menjadi 
salah satu pengukuran kinerja manajer, sehingga kondisi keuangan perusahaan yang bermasalah dapat mendorong manajer mengatur tingkat konservatisme akuntansi (Sulastri dan Anna, 2018). Selain hal tersebut diatas, ada faktor lainnya yaitu earning pressure, Wijaya dan Martani (2011) menyatakan bahwa perusahaan perusahaan yang labanya sudah mencapai target yang ditetapkan, penurunan laba yang dilakukan dapat dikurangi dengan earnings pressure. Apabila laba tahun berjalan sudah melebihi target yang ditetapkan manajer (minimal sama dengan laba tahun lalu), maka perusahaan dapat melakukan penurunan akrual yang bersifat menurunkan laba untuk melakukan income smoothing. Penelitian tentang konservatisme akuntansi sudah banyak dilakukan, tetapi hasilnya masih belum konsisten. Penelitian sebelumnya menunjukkan adanya perbedaan antara hasil peneliti satu dengan peneliti yang lain. Penelitian yang dilakukan oleh Rahmawati (2017) pada perusahaan manufaktur mengatakan bahwa tax incentive dan earning pressure tidak berpengaruh terhadap accounting conservatism. Sedangkan leverage berpengaruh terhadap accounting conservatism.

Kemudian pada tahun selanjutnya, penelitian yang dilakukan oleh Rahayu (2018) pada perusahaan manufaktur mengatakan bahwa financial distress dan leverage berpengaruh pada accounting conservatism. Sementara itu, ukuran perusahaan dan tax incentive tidak berpengaruh terhadap accounting conservatism.

Pada tahun yang sama, penelitian yang dilakukan oleh Sumantri (2018) terhadap perusahaan manufaktur mengatakan bahwa tax incentive dan growth opportunity memiliki pengaruh positif terhadap accounting conservatism, sedangkan leverage memiliki pengaruh negatif terhadap accounting conservatism.
Perbedaan penelitian ini dengan penelitian-penelitian sebelumnya seperti yang telah dilakukan oleh Rahayu (2018) dengan financial distress, ukuran perusahaan, leverage dan tax incentive sebagai variabel independen dan sampel yang digunakan adalah perusahaan manufaktur. Sedangkan pada penelitian ini menggunakan variabel insentif pajak, financial distress dan earning pressure sebagai variabel independen dan sampel yang kami gunakan adalah perusahaan manufaktur dengan khusus mengambil sub sektor industri barang konsumsi yang terdaftar di Bursa Efek Indonesia dari tahun 2013 sampai dengan 2017.

Berdasarkan uraian diatas, penulis berkontribusi untuk dapat mengetahui pengaruh insentif pajak, financial distress, earning pressure terhadap konservatisme akuntansi. Harapannya, penelitian ini akan dijadikan rekomendasi oleh perusahaan dan regulator.

Penelitian ini menggunakan teori yang relevan yaitu teori agensi. Teori tersebut memegang peran penting dalam praktik bisnis perusahaan. Menurut Jensen dan Meckling (1976) bahwa konsep teori agensi atau agency theory merupakan hubungan keagenan sebagai suatu kontrak yang mana satu atau lebih prinsipal (pemegang saham) menggunakan pihak lain atau agen (manajer) untuk menjalankan aktifitas perusahaan. Principal ini dapat menyediakan fasilitas dan dana untuk kebutuhan operasi perusahaan, sedangkan untuk agen sebagai pihak pengelola berkewajiban dalam mengelola perusahaan sebagaimana yang telah dipercayakan oleh pemegang saham (principal) dalam hal meningkatkan nilai perusahaan. Adapun tujuan utama dari teori keagenan ialah untuk menjelaskan bagaimana pihak - pihak yang melakukan hubungan kontrak dapat mendesain kontrak tersebut dan tujuannya untuk meminimalisasi biaya/cost sebagai dampak adanya informasi yang tidak 
simetris. Pada praktiknya di perusahaan pihak agen dalam aktifitasnya terkadang tidak sesuai dengan kontrak kerja yang disepakati dari awal yaitu untuk meningkatkan kemakmuran pemegang saham, melainkan cenderung untuk keuntungan kepentingan diri sendiri, sehingga muncul suatu konflik keagenan. Penelitian ini juga menggunakan teori signaling, dimana teori ini menekan kepada pentingnya informasi yang dikeluarkan oleh perusahaan terhadap keputusan investasi dari pihak luar perusahaan. Informasi merupakan unsur penting bagi investor dan pelaku bisnis karena informasi pada hakekatnya menyajikan keterangan, catatan atau gambaran baik untuk keadaan masa lalu, saat ini maupun keadaan masa mendatang bagi kelangsungan hidup suatu perusahaan dan bagaimana pasaran efeknya. Pengambilan keputusan investasi para investor di pasar modal membutuhkan informasi yang lengkap, relevan, akurat dan tepat waktu sebagai alat analisis. Pada praktiknya manajemen menerapkan kebijakan konservatisme akuntansi dengan cara menghitung depresiasi yang tinggi yang akan menghasilkan laba rendah yang relatif permanen, artinya tidak mempunyai pengaruh sementara pada penurunan laba yang akan berbalik pada masa yang akan datang (Fitriani dkk, 2015). Pada penelitian ini, Penulis memaparkan hipotesis sebagai berikut :

Rahmawati (2018) menyebutkan semakin besar perusahaan maka semakin besar perhatian pemerintah terhadap perusahaan tersebut dan semakin besar kemungkinan untuk diatur. Penelitian ini memprediksi bahwa perusahaan dengan pajak semakin besar maka cenderung memilih akuntansi yang lebih konservatif.

$\mathrm{H}_{1}$ : insetif pajak berpengaruh terhadap konservatisme akuntansi.

Guna mengatasi dan meminimalisasi terjadinya kebangkrutan, maka perusahaan dapat mengawasi kondisi keuangan dengan menggunakan teknik - teknik analisis laporan keuangan. Analisis laporan keuangan merupakan alat yang penting dalam memperoleh informasi yang berkaitan dengan posisi keuangan perusahaan yang telah ditetapkan oleh perusahaan. Analisis laporan keuangan perusahaan yang diterapkan akan dapat mengetahui kondisi dan perkembangan financial perusahaan (Rahayu, 2018).

Berdasarkan penelitian Noviantari dan Ratnadi (2015), dalam penelitiannya: Pengaruh Financial Distress, Ukuran Perusahaan, Leverage pada accounting conservatism menunjukan bahwa kondisi keuangan yang bermasalah diakibatkan oleh kualitas manajer perusahaan yang buruk. Tingginya financial distress manajer perusahaan kemungkinan akan menghadapi tekanan pelanggaran kontrak. Tentu saja dapat menjadi sebuah ancaman bagi manajer yang bersangkutan, sehingga manajer menggunakan prinsip accounting conservatism untuk penyajian laporan keuangan yang dapat menghindari kemungkinan konflik dengan kreditur dan pemegang saham. Financial distress (tingkat kesulitan keuangan) yang semakin tinggi mengakibatkan laporan keuangan yang dihasilkan akan semakin tidak konservatif. Berdasarkan uraian diatas, maka dirumuskan hipotesis sebagai berikut: $\mathrm{H}_{2}$ : Financial Distress berpengaruh terhadap konservatisme akuntansi.

Untuk perusahaan yang laba/keuntungannya tidak mencapai target, penurunan laba dilakukan untuk tujuan pajak dapat dikurangi oleh earning pressure, hal ini untuk meningkatkan laba akuntansi. Perusahaan yang memperoleh laba (profit firm), ketika labanya telah mencapai atau bahkan melebihi dari target, maka penurunan laba yang dilakukan untuk tujuan pajak dapat dikurangi pada earning 
pressure guna melakukan income smooting. Sedangkan untuk perusahaan yang mengalami kerugian (loss firm), maka cederung melakukan earning bath dan ini berguna memperoleh kompensasi pajak. Penelitian yang dilakukan oleh Raharja dan Sandra (2014), hasilnya menyebutkan bahwa earning presuure berpengaruh terhadap accounting conservatism. Hasil penelitian tersebut berbeda dengan hasil penelitian Handayani (2016) dan Rahmawati (2017) yang mengemukakan bahwa earning pressure tidak berpengaruh terhadap accounting conservatism. Berdasarkan uraian diatas, maka peneliti merumuskan hipotesis sebagai berikut:

$\mathrm{H}_{3}$ : Earning Pressure tidak berpengaruh terhadap konservatisme akuntansi.

Kerangka konseptual dalam penelitian ini dibentuk untuk menggambarkan hubungan antara variabel independen dengan variabel dependen. Kerangka Konseptual dapat terlihat pada gambar dibawah ini:

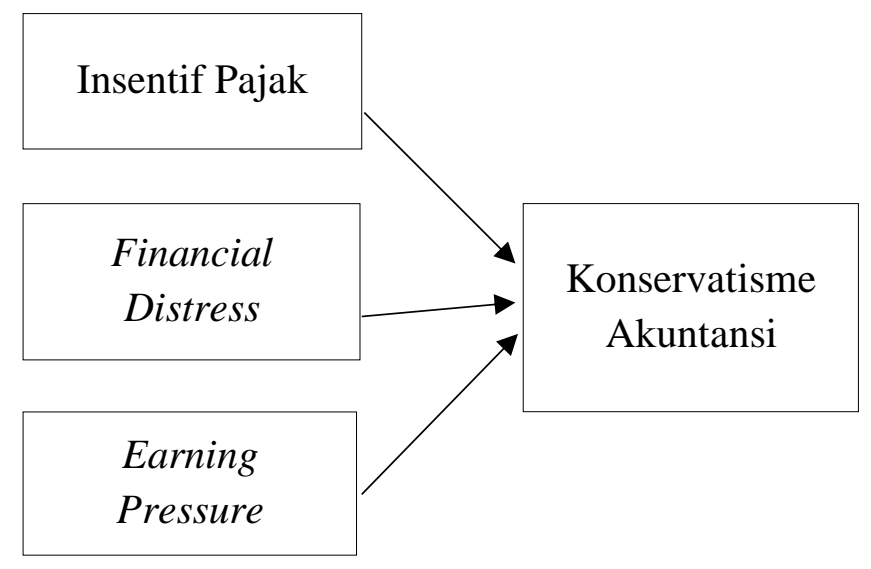

Gambar 1. Kerangka Konseptual

Sumber: Hasil Analisis, 2019

\section{METODE PENELITIAN}

\section{Sumber Data}

Data yang dipergunakan dalam penelitian ini adalah data sekunder berupa data laporan keuangan perusahaan manufaktur sub sektor industri barang konsumsi yang didapat dari Bursa Efek Indonesia pada tahun 2013 sampai tahun 2017, yang diperoleh melalui website resmi Bursa Efek Indonesia di www.idx.co.id.

\section{Populasi dan Sampel}

Populasi yang dipakai oleh peneliti ialah perusahaan manufaktur sub sektor industri barang konsumsi yang terdaftar di Bursa Efek Indonesia (BEI) periode dari tahun 2013 sampai dengan 2017, sebanyak 43 perusahaan. Adapun penentuan sampel pada penelitian ini berdasarkan purposive sampling. Pada penelitian ini terdapat 23 perusahaan yang dapat dijadikan sampel sesuai kriteria. Sehingga total sampel dalam penelitian ini adalah 115 sampel data laporan keuangan. 
Tabel 1.

Operasional Variabel dan Pengukuran

\begin{tabular}{|c|c|c|c|}
\hline $\begin{array}{c}\text { Variabel yang } \\
\text { diukur }\end{array}$ & Indikator & Skala & $\begin{array}{c}\text { Sumber } \\
\text { Data }\end{array}$ \\
\hline $\begin{array}{c}\text { Konservatisme } \\
\text { Akuntansi (Y) }\end{array}$ & CONNAC $=\frac{(N I O+D E P-C F O) x(-1)}{\text { Total Aset }}$ & Rasio & Sekunder \\
\hline $\begin{array}{c}\text { Insentif Pajak } \\
\left(\mathrm{X}_{1}\right)\end{array}$ & TAXPLAN $(T P)=\frac{\text { Tarif PPh } x(P T I-C T E)}{T A}$ & Rasio & Sekunder \\
\hline $\begin{array}{c}\text { Financial } \\
\text { Distress }\left(\mathrm{X}_{2}\right)\end{array}$ & $Z-S c o r e=1,2 X_{1}+1,4 X_{2}+3,3 X_{3}+0,6 X_{4}+1,0 X_{5}$ & Rasio & Sekunder \\
\hline $\begin{array}{c}\text { Earning } \\
\text { Pressure }\left(\mathrm{X}_{3}\right)\end{array}$ & $E P=\frac{L_{i t}-\left(L_{i t-1}\right)}{T A_{0}}$ & Rasio & Sekunder \\
\hline
\end{tabular}

Sumber: Hasil Analisa Penelitian sebelumnya, 2019

\section{HASIL DAN PEMBAHASAN Analisis Statistik Deskriptif}

Tabel 2.

Hasil Uji Statistik Deskriptif

\begin{tabular}{|l|c|r|r|r|c|}
\hline & N & \multicolumn{1}{|c|}{ Min } & Max & \multicolumn{1}{c|}{ Mean } & \multicolumn{1}{c|}{$\begin{array}{l}\text { Std. } \\
\text { Deviation }\end{array}$} \\
\hline & 95 &,- 02 &, 10 &, 0314 &, 02518 \\
\hline Insentif Pajak & 95 & 1,46 & 5,84 & 33,365 &, 95585 \\
\hline $\begin{array}{l}\text { Financial } \\
\text { Distress }\end{array}$ & 95 &,- 10 &, 16 &, 0091 &, 03830 \\
\hline $\begin{array}{l}\text { Earning } \\
\text { Pressure }\end{array}$ & 95 &,- 46 &, 05 &,- 1905 &, 10392 \\
\hline $\begin{array}{l}\text { Konservatisme } \\
\text { Akuntansi }\end{array}$ & 95 & & & & \\
\hline $\begin{array}{l}\text { Valid N } \\
\text { (listwise) }\end{array}$ & & & & & \\
\hline
\end{tabular}

Sumber: Output SPSS versi 24

Berdasarkan tabel diatas, insetif pajak memiliki nilai minimum sebesar -0,02 yang diperoleh dari perusahaan Sekar Laut Tbk (SKLT) pada tahun 2016 dan nilai maksimum sebesar 0,10 yang diperoleh perusahaan Unilever Indonesia Tbk (UNVR) pada tahun 2014. Nilai rata-rata (mean) dari insetif pajak adalah 0,0314 dengan nilai standar deviasi sebesar
0,02518. Financial Distress memiliki nilai minimum sebesar 1,46 yang diperoleh dari perusahaan Indofood Sukses Makmur Tbk (INDF) pada tahun 2013 dan nilai maksimum sebesar 5,84

yang diperoleh dari perusahaan Akasha Wira International Tbk (ADES) pada tahun 2013. Nilai rata-rata (mean) dari financial distress adalah 3,3365 dengan nilai standar deviasi sebesar 0,95585. Earning Pressure memiliki nilai minimum sebesar -0,10 yang diperoleh dari perusahaan Wilmar Cahaya Indonesia Tbk (CEKA) pada tahun 2017 dan nilai maksimum sebesar 0,16 yang diperoleh dari perusahaan Sekar Bumi Tbk (SKBM) pada tahun 2013. Nilai rata-rata (mean) dari earning pressure adalah 0,0091 dengan nilai standar deviasi sebesar 0,03830. Konservatisme Akuntansi memiliki nilai minimum sebesar -0,46 yang diperoleh dari perusahaan Pyridam Farma Tbk (PYFA) pada tahun 2016 dan nilai maksimum sebesar 0,05 yang diperoleh dari perusahaan Merck Indonesia Tbk (MERK) 
pada tahun 2014. Nilai rata-rata (mean) dari konservatisme akuntansi adalah -0,1905 dengan nilai standar deviasi sebesar 0,10392 .

\section{Uji Hipotesis}

\section{Analisis Regresi Linear Berganda}

Tabel 3

Uji Regresi Berganda

\begin{tabular}{|c|c|c|c|c|c|}
\hline \multicolumn{6}{|c|}{ Coefficients $^{a}$} \\
\hline \multirow{2}{*}{ Model } & \multicolumn{2}{|c|}{$\begin{array}{l}\text { Unstandardize } \\
\text { d Coefficients }\end{array}$} & \multirow{2}{*}{$\begin{array}{c}\begin{array}{c}\text { Standardize } \\
\mathrm{d} \\
\text { Coefficients }\end{array} \\
\text { Beta }\end{array}$} & \multirow{2}{*}{$\mathrm{t}$} & \multirow{2}{*}{ Sig. } \\
\hline & B & $\begin{array}{l}\text { Std. } \\
\text { Error }\end{array}$ & & & \\
\hline (Constant &,- 084 &, 041 & & $\begin{array}{r}- \\
2,05 \\
6\end{array}$ & $\begin{array}{r}, 04 \\
3\end{array}$ \\
\hline $\begin{array}{l}\text { Insentif } \\
\text { Pajak }\end{array}$ & 2,118 & ,590 & ,513 & $\begin{array}{r}3,58 \\
9\end{array}$ & $\begin{array}{r}, 00 \\
1\end{array}$ \\
\hline $\begin{array}{l}\text { Financial } \\
\text { Distress }\end{array}$ &,- 051 & ,015 &,- 469 & $\begin{array}{r}- \\
3,40 \\
7\end{array}$ & $\begin{array}{r}, 00 \\
1\end{array}$ \\
\hline $\begin{array}{l}\text { Earning } \\
\text { Pressure }\end{array}$ &,- 378 & ,279 &,- 139 & $\begin{array}{r}- \\
1,35 \\
7 \\
\end{array}$ & $\begin{array}{r}, 17 \\
8\end{array}$ \\
\hline
\end{tabular}

Sumber: Output SPSS versi 24

Dari tabel diatas dapat dirumuskan regresi linear berganda sebagai berikut:

$\mathrm{Y}=\mathrm{a}+\mathrm{b}_{1} \mathrm{X}_{1}+\mathrm{b}_{2} \mathrm{X}_{2}+\mathrm{b}_{3} \mathrm{X}_{3}+\mathrm{e}$

$Y=-0,084+2,118 X_{1}-0,051 X_{2}-0,378 X_{3}+e$

Berdasarkan rumus diatas dapat dijelaskan bahwa konstanta sebesar -0,084 artinya jika Insentif Pajak, Financial Distress, Earning Pressure, dianggap konstan, maka Accounting Conservatism nilainya akan menurun sebesar -0,084. Nilai koefisien regresi Tax Incentive (b) bernilai positif yaitu 2,118, ini dapat diartikan bahwa setiap peningkatan Tax Incentive sebesar 1\% maka Accounting Conservatism akan mengalami kenaikan sebesar 2,118. Nilai koefisien regresi Financial Distress (b) bernilai negatif yaitu sebesar $-0,051$, ini dapat diartikan bahwa setiap peningkatan Financial Distress sebesar 1\% maka Accounting Conservatism akan mengalami menurun sebesar -0,05. Nilai koefisien regresi Earning Pressure (b) bernilai negatif yaitu $-0,378$ ini dapat diartikan bahwa setiap peningkatan Earning Pressure sebesar 1\% maka Accounting Conservatism akan menurun sebesar -0,378.

Berdasarkan tabel diatas, jika mengacu pada tingkat signifikansi 0.05 atau 5\% menunjukkan bahwa tax incentive memiliki nilai $t_{\text {hitung }} 3,589$ dan nilai $t_{\text {tabel }}$ sebesar 1,66159. Serta nilai signifikan yang diperoleh tax incentive sebesar 0,001 dan nilai signifikansi 0,05 maka $0,001<0,05$. Sehingga hal ini menandakan $\mathrm{H}_{1}$ diterima, maka tax incentive berpengaruh terhadap accounting conservatism. Financial distress memiliki nilai $t_{\text {hitung }}$ sebesar $-3,407$ dan nilai $\mathrm{t}_{\text {tabel }}$ sebesar 1,66159. Serta nilai signifikan yang diperoleh financial distress sebesar 0,001 dan nilai signifikansi 0,05 maka $0,001<0,05$. Sehingga hal ini $\mathrm{H}_{2}$ diterima, maka financial distress berpengaruh terhadap accounting conservatism. Earning pressure memiliki nilai thitung sebesar $-1,357$ dan nilai $t_{\text {tabel }}$ sebesar 1,66159. Serta nilai signifikan yang diperoleh earning pressure sebesar 0,178 dan nilai signifikansi 0,05 maka $0,178>0,05$. Sehingga hal ini $\mathrm{H}_{3}$ ditolak, maka earning pressure tidak berpengaruh terhadap Konservatisme Akuntansi.

\section{SIMPULAN}

Berdasarkan hasil penelitian berupa bukti empiris pada perusahaan manufaktur 
sub sektor industri barang konsumsi yang didapat dari Bursa Efek Indonesia: tax incentive, financial distress, earning pressure terhadap accounting conservatism, maka dapat diambil kesimpulan bahwa insetif pajak berpengaruh terhadap konservatisme akuntansi. Hasil penelitian ini menunjukkan bahwa tingkat pengggunaan insentif pajak dalam suatu perusahaan mempengaruhi tingkat konservatisme akuntansi suatu perusahaan, karena pajak penghasilan telah lama dikaitkan dengan laba perusahaan dan akibatnya mempengaruhi kalkulasi laporan laba perusahaan. Pajak penghasilan mempengaruhi pelaporan keuangan dalam metode akuntansi, maka perlambatan pengakuan pendapatan dan percepatan pengakuan biaya akan terjadi penundaan pembayaran pajak. Dengan demikian, semakin besar perusahaan, maka semakin besar pula perhatian pemerintah terhadap perusahaan tersebut dan semakin besar kemungkinan untuk perusahaan melakukan tax planning dalam memaksimalkan laba perusahaan. Hasil penelitiaan ini juga mendukung penelitian Rufaidah (2017) dan Handayani dkk (2015) menyebutkan bahwa pengurangan tarif pajak yang diberlakukan pemerintah, maka manajer perusahaan berupaya memaksimalkan nilai perusahaan dengan meminimalkan beban pajak.

Financial Distress berpengaruh terhadap konservatisme akuntansi. Hasil penelitian ini sejalan dengan penelitian yang dilakukan oleh Suryadari dan Priyanto (2012), Viola dan Patricia (2016) serta Sulastri (2018) yang mengatakan financial distress berpengaruh terhadap konservatisme akuntansi. Faktor Financial distress merupakan tahap penurunan kondisi keuangan yang terjadi sebelum terjadinya kebangkrutan ataupun likuidasi perusahaan (Sulastri, 2018). Laba merupakan salah satu faktor yang dipengaruhi oleh financial distress. Selain itu, laba juga merupakan salah satu faktor yang mempengaruhi bagaimana cerminan bagi penerapan konservatisme akuntansi. Pada saat laba kecil, nilai Altman Z-score kecil dan mengindikasikan penerapan prinsip konservatisme akuntansi yang tinggi, begitu pula sebaliknya. Konservatisme akuntansi ini diterapkan pada saat kerugian terjadi maka seluruh kerugian tersebut akan langsung diakui meskipun belum terealisasi, akan tetapi ketika keuntungan/laba terjadi, maka keuntungan/laba yang belum terealisasi tidaklah diakui. Financial distress perusahaan berpengaruh secara signifikan terhadap konservatisme akuntansi. Pada saat kondisi keuangan perusahaan bermasalah, manajer cenderung menerapkan konservatisme akuntansi dalam hal mengurangi konflik antara investor dan kreditor. Prinsip konservatisme akuntansi merupakan prinsip kehati - hatian, oleh karenanya ketika adanya perusahaan mengalami kesulitan keuangan, maka mendorong perusahaan akan lebih berhati hati dalam menghadapi lingkungan yang tidak pasti. Oleh karenanya, semakin tinggi financial distress perusahaan, maka akan mendorong manajer untuk menaikan tingkat konservatisme akuntansi dan sebaliknya jika semakin rendah financial distress, maka manajer akan menurunkan tingkat konservatisme akuntansi.

Earning Pressure tidak berpengaruh terhadap konservatisme akuntansi. Faktor Earning pressure tidak turut dalam mempengaruhi keputusan manajer dalam penurunan laba, jika laba yang diperoleh 
perusahaan melebihi target yang diharapkan dalam tujuan pajak melalui konservatisme akuntansi, maka hal ini menunjukkan bahwa laba diperoleh dari hasil operasional perusahaan. Jika perusahaan mengalami penurunan laba karena operasional perusahaan, maka tidak berdampak pada kebijakan akuntansi yang ditetapkan perusahaan. Hasil penelitian ini sejalan dengan penelitian yang dilakukan oleh Rahmawati (2017) serta Wicaksono dan Laksito (2012) yang mengatakan bahwa earning pressure tidak berpengaruh terhadap konservatisme akuntansi.

\section{DAFTAR PUSTAKA}

Ardina, A. M. (2012). Penggunaan Perspektif Positive Accounting Theory terhadap Konsevatisme Akuntansi. Dipenegoro Journal of Accounting, 1(1), 1-15.

Firmasari, D. (2016). Pengaruh Leverage, Ukuran Perusahaan, dan Financial Distress terhadap Konservatisme Akuntansi (Doctoral dissertation, Airlangga University).

Verawaty, V., \& Merina, C. (2015). Insentif Pemerintah (Tax Incentives) dan Faktor Non Pajak Terhadap Konservatisme Akuntansi Perusahaan Perbankan di Indonesia. Proceeding Sriwijaya Economic and Business Converence.

Handayani, A. S., Darmayanti, Y., \& Hamdi, M. (2015). Pengaruh Insentif Pajak Dan Faktor Non Pajak Terhadap Konservatisme Akuntansi Pada Perusahaan Manufaktur Terdaftar Di Bursa Efek Indonesia.

Marlina, A. (2016). Pengaruh Leverage dan Financial Distress Terhadap Tingkat Konservatisme Akuntansi. Sekolah Tinggi Ilmu Ekonomi Perbanas Surabaya.

Noviantari, N. W., \& Ratnadi, N. M. D. (2015). Pengaruh financial distress, ukuran perusahaan, dan leverage pada konservatisme akuntansi. E-Jurnal Akuntansi, 646660.

Hasanah, N. (2016). Analisis rasio keuangan model altman dan model springate sebagai early warning system terhadap prediksi kondisi bermasalah pada bank go public.

Amalia, S. (2016). Pengaruh Insentif Pajak dan Faktor Non Pajak Terhadap Konservatisme Akuntansi Pada Perusahaan Manufaktur Yang Terdaftar di Bursa Efek Indonesia (Doctoral dissertation, UNIVERSITAS STIKUBANK).

Rahayu, S. (2018). Pengaruh financial distress, ukuran perusahaan, leverage dan insentif pajak terhadap konservatisme akuntansi (studi empiris pada perusahaan manufaktur sektor industri dasar dan kimia yang terdaftar di bursa efek indonesia tahun 20112016).

Rahmawati, A. D. (2017). Pengaruh insentif pajak, earning pressure, dan leverage terhadap konservatsime akuntansi (studi kasus pada perusahaan manufaktur sektor industri barang konsumsi yang terdaftar di bursa efek indonesia tahun 2011-2016).

Rufaidah, A. R. (2017). Pengaruh insentif pajak, leverage dan likuiditas terhadap konservatisme akuntansi (studi empiris pada perusahaan manufaktur sub sektor farmasi yang terdaftar di bursa efek indonesia tahun 2013-2016).

Savitri, E. (2016). Konservatisme Akuntansi. Cara Pengukuran, Tinjauan Empiris dan Faktor-faktor yang Mempengaruhinya. 
Sudarsono, B. (2019). Pengaruh Inventory Intensity dan Capital Intensity terhadap Agresivitas Pajak. Studi Kasus pada Perusahaan Manufaktur yang terdaftar di Bursa Efek Indonesia tahun 2014-2016.

Sulastri, A., Mulyati, S., \& Icih, I. (2018). Analisis Pengaruh ASEAN Corporate Governance Scorecard, Leverage, Size, Growth Opportunities, dan Earnings Pressure terhadap Konservatisme Akuntansi (Studi Kasus pada Perusahaan Top Rank 50 ASEAN Corporate Governance Scorecard di Indonesia yang Terdaftar. Accruals (Accounting Research Journal of Sutaatmadja), 2(1), 41-67.

Sulastri, S., \& Anna, Y. D. (2018). Pengaruh financial distress dan leverage terhadap konservatisme akuntansi. Akuisisi: Jurnal Akuntansi, 14(1), 59-69..

SUMANTRI, I. I. (2018). Pengaruh Insentif Pajak, Growth Opportunity, dan Leverage Terhadap Konservatisme Akuntansi.Jurnal Ilmiah Akuntansi Universitas Pamulang, 6(1), 122-145.

Sunyoto, D. (2016). Metodologi Penelitian Akuntansi. Repika Aditama.

Suryandari, E., \& Priyanto, R. E. (2016). Pengaruh Risiko Litigasi dan Tingkat Kesulitan Keuangan Perusahaan Terhadap Hubungan Antara Konflik Kepentingan dan Konservatisme Akuntansi. Journal of Accounting and Investment, 12(2), 161-174.

Tanjung, D. D. (2019). Pengaruh insentif pajak, financial distress dan leverage dan terhadap konservatisme akuntansi (studi empiris pada perusahaan manufaktur yang terdaftar di Bursa efek indonesia tahun 2012-2016).

Tanu, T. (2017). Pengaruh insentif pajak, tingkat utang dan ukuran perusahaan terhadap konservatisme akuntansi (studi kasus pada perusahaan manufaktur sektor aneka industri yang terdaftar di bursa efek indonesia tahun 2011-2015).

Viola, V., \& Diana, P. (2016). Pengaruh Kepemilikan Managerial, Leverage, Financial Distress Dan Kepemilikan Publik Terhadap Konservatisme Akuntansi. Ultimaccounting: Jurnal Ilmu Akuntansi, 8(1), 22-36.

Wicaksono, W. S., \& Laksito, H. (2012). Uji Empiris Pengaruh Faktor-Faktor Konservatisme Akuntansi dalam Perpajakan (Doctoral dissertation, Fakultas Ekonomika dan Bisnis).

Wijaya, M., \& Martani, D. (2011). Praktik Manajemen Laba Perusahaan Dalam Menanggapi Penurunan Tarif Pajak Sesuai UU No. 36 Tahun 2008. Dalam Simposium Nasional XIV Aceh.

Ilham, E., \& Wulandari, I. (2014). Pengaruh Struktur Kepemilikan Manajerial, Debt Covenant dan Growth Opportunities terhadap Konservatisme Akuntansi (Doctoral dissertation, Riau University).

www.idx.co.id

www.google.scholar.co.id. 